\title{
Membrane divided soluble lead battery utilising a bismuth electrolyte additive
}

\section{L.P.J. Wallis and R.G.A. Wills}

Faculty of Engineering and the Environment, University of Southampton, Southampton SO17 1BJ, United Kingdom

\begin{abstract}
A soluble lead battery benefiting from the incorporation of an ion exchange membrane to separate the positive and negative electrolyte compartments has been described. A static cell, using an electrolyte volume of $7.5 \mathrm{ml}$, was configured with and without a membrane. The use of a membrane enables the selection of electrode specific additives. In this paper, a proof of concept cell is shown with the use of $\mathrm{Bi}^{3+}$, which when added to the positive electrolyte compartment leads to a twenty-fold increase in cycle life of the cell. The bismuth ions cause a shift in the reaction mechanism and kinetics of lead dioxide dissolution during the discharge reaction.
\end{abstract}

Keywords: Lead acid, methanesulfonic acid, lead dioxide, bismuth, soluble lead battery

\section{Author for correspondence:}

Dr Richard Wills

Faculty of Engineering and the Environment, The University of Southampton, Highfield, UK, SO17 1BJ

Email:rgaw@soton.ac.uk 


\section{Introduction}

Recent literature has described the design, characterisation and chemistry of the soluble lead flow battery [1-3]. This battery utilises an electrolyte comprising $\mathrm{Pb}^{2+}$ ions solvated in aqueous methanesulfonic acid. During charge, solid lead and lead dioxide deposits are electroplated onto the negative and positive electrodes respectively. During discharge, the electrodeposits are electrochemically converted back to soluble $\mathrm{Pb}^{2+}$ ions. Unlike many flow batteries, no ion exchange membrane has been used in studies of this system as the same electrolyte is required for the positive and negative electrode reactions and the solid phases of the charged state prevents significant self-discharge of the cell. Flow batteries without an ion exchange membrane benefit significantly from reduced cell complexity and cost. As a consequence, the incorporation of a membrane into the soluble lead system would only be beneficial if; (1) the added cost of the membrane was offset by extended operational lifetime and (2) the increased cell resistance associated with the membrane was offset by improved efficiency or an increased cell potential (hence higher battery voltage and power). Currently, cycle life and efficiency limitations of the soluble lead battery are primarily associated with; (1) morphology of the electrode deposits (dendritic/spongy $\mathrm{Pb}$ and creeping $\mathrm{PbO}_{2}$ formations) and (2) reversibility of the positive electrode reaction [1, 4-6]. The use of electrolyte additives can be employed to improve the efficiency and reversibility of the electrode reactions. Numerous electrolyte additives have been selected and trialled, including fluorosurfactants, sulphates, ammines and metal ions $[1,7,8]$. None, however, have successfully addressed the issues with both electrode reactions. A motivation for the incorporation of a membrane is the possibility of using electrode specific electrolyte additives. $\mathrm{Bi}^{3+}$ ions are used as dopants for the 
positive active mass in conventional (sulphuric acid electrolyte, pasted electrodes) lead acid batteries. They are thought to increase the specific capacity of the positive active mass and accelerate oxygen transition reactions within the $\mathrm{PbO}_{2}$ phases $[9,10]$. In this work it is shown that $\mathrm{Bi}^{3+}$ ions provide beneficial performance improvements for the positive electrode reactions $\left(\mathrm{PbO}_{2}\right.$ deposition and dissolution) but adversely affect the negative electrode performance. A unit cell is utilised to demonstrate the soluble lead battery operating with a Nafion ${ }^{\circledR}$ ion exchange membrane where $\mathrm{Bi}^{3+}$ is added to the positive electrolyte solution only to give enhanced charge efficiency and cycle life. 


\section{Experimental details}

All solutions were prepared using water from a Purite Ondeo 15 purifier, methanesulfonic acid $\left(\mathrm{CH}_{3} \mathrm{SO}_{3} \mathrm{H}\right)$ from BASF, lead carbonate $\left(\mathrm{Pb}\left(\mathrm{CO}_{3}\right)_{2}\right)$ from Sigma Aldrich and bismuth oxide $\left(\mathrm{Bi}_{2} \mathrm{O}_{3}\right)$ from Sigma Aldrich. The preparation of the electrolyte solutions has previously been described. ${ }^{3}$ Three stock electrolytes were used in these studies:

- Voltammetry of the negative electrode reactions used an electrolyte solution comprising $10 \mathrm{mmol} \mathrm{dm}{ }^{-3} \mathrm{~Pb}^{2+}$ in aqueous $\mathrm{CH}_{3} \mathrm{SO}_{3} \mathrm{H}\left(1.0 \mathrm{~mol} \mathrm{dm}^{-3}\right)$.

- Voltammetry of the positive electrode reactions used an electrolyte solution comprising $0.5 \mathrm{~mol} \mathrm{dm}^{-3} \mathrm{~Pb}^{2+}$ in aqueous $\mathrm{CH}_{3} \mathrm{SO}_{3} \mathrm{H}\left(1.0 \mathrm{~mol} \mathrm{dm}{ }^{-3}\right)$.

- Unit cells were supplied with an electrolyte solution initially comprising $1.5 \mathrm{~mol}$ $\mathrm{dm}^{-3} \mathrm{~Pb}^{2+}$ in aqueous $\mathrm{CH}_{3} \mathrm{SO}_{3} \mathrm{H}\left(1.0 \mathrm{~mol} \mathrm{dm}^{-3}\right)$.

Where stated, $10 \mathrm{mmol} \mathrm{dm}^{-3}$ of $\mathrm{Bi}^{3+}$ was added to these stock electrolytes.

Voltammetric studies of the $\mathrm{Pb} / \mathrm{Pb}^{2+}$ and $\mathrm{PbO}_{2} / \mathrm{Pb}^{2+}$ electrode couples utilised a standard two compartment, three-electrode glass electrochemical cell containing approximately 25 $\mathrm{cm}^{3}$ of electrolyte and was setup as previously described [3]. The working electrode was a glassy carbon disc with area $0.07 \mathrm{~cm}^{2}$ and the counter electrode was a Pt wire. The working electrode was rotated at $900 \mathrm{rpm}$ in all voltammetric studies. Potentials were measured against a saturated calomel reference (SCE) electrode. The electrochemical cell was maintained at $293 \mathrm{~K}$ and controlled using an EG\&G model 263A potentiostat operating with EG\&G PowerSuite software.

A parallel plate unit cell was constructed using Entegris carbon-polymer composite for the positive electrode and nickel foil for the negative electrode. The cell wall was 
constructed from two silicone rubber gaskets (RS 506-3264). Both electrodes were planar with geometric active surface area of $25 \mathrm{~cm}^{2}$. A schematic of the cell is presented in figure 1.

The electrolyte chamber is $50 \times 60 \times 3 \mathrm{~mm}$, as each gasket is $1.5 \mathrm{~mm}$ in thickness. Between the gaskets was placed a Nafion ${ }^{\circledR} \mathrm{NF} 115 / \mathrm{H}^{+}$membrane in three of the five cell configurations, which are shown in table 1.

The unit cell was tested in five different configurations to assess the effects of using 1) $\mathrm{Bi}^{3+}$ as an electrolyte additive and 2) an ion exchange membrane to separate the positive and negative electrolyte chambers. Two cells, Lead1 and Bismuth1, were undivided (without a membrane) and three cells, Lead2, Bismuth2 and Bismuth3, were divided into separate electrode chambers using the Nafion ${ }^{\circledR}$ membrane. Bismuth2 had the additive added to both the positive and negative electrolyte chambers while Bismuth3 had the additive only added to the positive (lead dioxide) electrolyte chamber.

\section{FIGURE 1}

\section{TABLE 1}

Charge/discharge cycling of the cell was controlled using an MTI battery analyser operating with MTI Battery Analyzer software. Constant current charge and discharge cycling at $150 \mathrm{~mA}\left(6 \mathrm{~mA} \mathrm{~cm}^{-2}\right)$ was used throughout, which corresponds to the $\mathrm{C}_{1}$ charge rate for the volume of electrolyte contained within the cell. During cycling the battery was subjected to a series of 10 minute charge periods followed by full discharge. During charging, an upper cut off voltage of was $3 \mathrm{~V}$. Discharge periods were ended when a cut- 
off voltage of $1.4 \mathrm{~V}$ was reached. The charge passed during each cycle corresponds to $8.3 \%$ of the charge contained in the $7.5 \mathrm{ml}$ of electrolyte within the cell electrolyte chamber. 


\section{Results and discussion}

\subsection{Voltammetry}

The repeated deposition and dissolution of $\mathrm{Pb}$ and $\mathrm{PbO}_{2}$ layers at a rotating disc electrode has been investigated with and without the presence of $\mathrm{Bi}^{3+}$ ions in the electrolyte solution. In figure 2, the first and two hundredth consecutive cyclic voltammograms are presented for the $\mathrm{Pb} / \mathrm{Pb}^{2+}$ redox couple. Each scan was performed immediately following the preceding one without cleaning the electrode or removing it from the electrolyte solution.

\section{FIGURE 2}

The electrochemical response is typical of a metal deposition-dissolution reaction and consistent with previously published data $[3,11]$. Sweeping from positive potentials in a negative direction, a cathodic reduction wave is observed at $-0.55 \mathrm{~V}$ vs. SCE corresponding to the nucleation and deposition of metallic lead on the electrode surface. The current density, $j$, increases rapidly to a mass-transport limited plateau of $5 \mathrm{~mA} \mathrm{~cm}{ }^{-2}$. On the backward scan, from $-0.7 \mathrm{~V} v$. SCE moving towards more positive potentials, the deposition of lead continues until $-0.48 \mathrm{~V} v s$. SCE. At potentials more positive than this a sharp anodic oxidation peak is observed corresponding to the electrochemical stripping of the lead deposit. Between the second and fifth voltammograms the potential at which lead deposition commences progressively becomes more positive to $-0.5 \mathrm{~V}$ vs. SCE. Following the fifth cycle this potential remained consistent. It is clear that the repeated 
deposition and stripping of lead can be achieved at an electrode surface with predictable, consistently high efficiencies and low overpotentials.

A similar set of voltammograms recorded for the $\mathrm{PbO}_{2} / \mathrm{Pb}^{2+}$ redox couple highlights some of the challenges associated with the soluble lead battery system. The $1^{\text {st }}, 5^{\text {th }}, 25^{\text {th }}$, $50^{\text {th }} 75^{\text {th }}$ and $100^{\text {th }}$ cyclic voltammograms are presented in figure 3 . During the first scan, sweeping towards positive potentials, $\mathrm{PbO}_{2}$ nucleation commences at $1.85 \mathrm{~V} v s$. SCE with deposition continuing during the backward scan until a potential of $1.50 \mathrm{~V} v s$. SCE. At potentials more negative than this the $\mathrm{PbO}_{2}$ is reduced, however, significant current densities are not achieved until the potential is more negative than $1.2 \mathrm{~V} v s$. SCE. The overpotentials associated with the $\mathrm{PbO}_{2} / \mathrm{Pb}^{2+}$ electrode couple are large and the kinetics of the reaction are slow in comparison with the $\mathrm{Pb} / \mathrm{Pb}^{2+}$ electrode couple. The poor reversibility of the positive electrode reactions is exacerbated with repeated voltammograms. It can be seen that by the one hundredth cycle, the dissolution reaction occurs over a broad potential range (between 1.5 and $0.2 \mathrm{~V} v$ s. SCE) rather than having a sharp reduction peak. Beyond the one hundredth cycle the stripping efficiency further deteriorates and was negligible by the $150^{\text {th }}$ cycle.

\section{FIGURE 3}

The electrochemical activity of $\mathrm{Bi}^{3+}$ ions in methanesulphonic acid has been assessed in the potential window of relevance for the soluble lead battery, -0.8 to $1.9 \mathrm{~V}$ vs. SCE, (figure 4). Sweeping the potential towards negative values, there is a cathodic reduction wave at $-0.29 \mathrm{~V} v s$. SCE corresponding to the nucleation and deposition of metallic 
bismuth. The current density rapidly increases to a mass transport limited plateau of 10 $\mathrm{mA} \mathrm{cm}{ }^{-2}$ and deposition continues on the backwards scan until a potential of $0.05 \mathrm{~V} v s$. SCE. At more positive potentials there is a sharp anodic oxidation peak corresponding to the dissolution of the bismuth deposit. The kinetics of the $\mathrm{Bi} / \mathrm{Bi}^{3+}$ electrode couple are rapid with significant current densities achieved at low overpotentials. At more positive potentials still there is negligible electrochemical activity in the potential window for the positive electrode reaction of the soluble lead battery (1.2 to $1.9 \mathrm{~V} v s$. SCE).

\section{FIGURE 4}

Comparing figures 2 and 4 the electropotential of the $\mathrm{Bi} / \mathrm{Bi}^{3+}$ redox couple is over half a volt more positive than the $\mathrm{Pb} / \mathrm{Pb}^{2+}$ redox couple. In the soluble lead battery, this would result in preferential deposition of $\mathrm{Bi}$ at the negative electrode. The electrochemistry of an electrolyte containing both $\mathrm{Pb}^{2+}$ and $\mathrm{Bi}^{3+}$ ions has been investigated between potential limits of $0.3 \mathrm{~V}$ and $-0.7 \mathrm{~V} v s$. SCE (figure 5). As expected, scanning towards negative potentials, there is a cathodic reduction wave at $-0.25 \mathrm{~V} v s$. SCE followed by a second cathodic reduction wave at $-0.48 \mathrm{~V} v s$. SCE corresponding to the deposition of bismuth and lead respectively. On the backward scan there is an anodic stripping peak associated with lead dissolution at circa $-0.45 \mathrm{~V}$ vs. SCE. The stripping peak associated with bismuth dissolution is observed at circa $0.1 \mathrm{~V}$ vs. SCE. Effectively, with $\mathrm{Bi}^{3+}$ present in the electrolyte, this metal electrodeposits first with lead plating into the bismuth and forming an alloy. In the soluble lead battery system, this would lead to rapid depletion of $\mathrm{Bi}^{3+}$ from the electrolyte. Furthermore, successive deposition and stripping 
voltammograms (figure 5) in the mixed metal ion electrolyte show that the efficiency of the lead stripping decreases with time. Table 2 compares the coulombic efficiency for the deposition and dissolution of $\mathrm{Pb}$ during sequentially run voltammograms using the stock electrolyte (no $\mathrm{Bi}^{3+}$ ) and one containing $10 \mathrm{mmol} \mathrm{dm}^{-3} \mathrm{Bi}^{3+}$. Without the bismuth the efficiency is relatively stable through the 200 scans, while with bismuth ions present the efficiency drops to less than $40 \%$ by the $200^{\text {th }}$ cycle.

\section{TABLE 2}

The effect of $\mathrm{Bi}^{3+}$ in the electrolyte was then similarly investigated for the positive electrode reaction $\left(\mathrm{PbO}_{2} / \mathrm{Pb}^{2+}\right.$ redox couple). Figure 6 shows the cyclic voltammograms. With the inclusion of $\mathrm{Bi}^{3+}$ in the electrolyte the kinetics of the $\mathrm{PbO}_{2} / \mathrm{Pb}^{2+}$ couple appear significantly improved. Over 100 consecutive cyclic voltammograms, the $\mathrm{PbO}_{2}$ stripping peak shifts positively from circa $0.95 \mathrm{~V} v s$. SCE to circa $1.4 \mathrm{~V}$ vs. SCE. Furthermore, comparing figures 3 and 6 shows that there is significantly less smearing of the stripping peak and the majority of the deposit is removed at significantly more positive potentials compared to the experiments without $\mathrm{Bi}^{3+}$ added to the electrolyte. A steady change in the electrode process can be seen with successive voltammograms resulting in the kinetics of the $\mathrm{Pb}^{2+} / \mathrm{PbO}_{2}$ reaction being dramatically enhanced.

\section{FIGURE 6}


Table 3 shows the coulombic efficiencies for selected voltammograms. Even at 150 consecutive cyclic voltammograms the charge efficiency is still around $80 \%$.

\section{TABLE 3}

A further consequence of the addition of bismuth ions to the electrolyte is a shift of the $\mathrm{PbO}_{2} / \mathrm{Pb}^{2+}$ equilibrium potential to more positive values. Table 4 summarises the effect. With no bismuth ions present, the equilibrium potential is $1.44 \mathrm{~V} v s$. SCE, whereas this increases to as the concentration of $\mathrm{Bi}^{3+}$ increases to $1.65 \mathrm{~V} v s$. SCE with the addition of $20 \mathrm{mmol} \mathrm{dm}{ }^{-3} \mathrm{Bi}^{3+}$. If this effect is transferred to the cell it would be advantageous in providing a higher open circuit voltage.

\section{TABLE 4}

\subsection{Unit cell}

Five cell configurations were subjected to charge/discharge cycle testing. The typical voltage profiles for each of the configurations are shown in figure 7. Cycle number is plotted along the x-axis, cell voltage along the $y$-axis and individual cycle time on the $\mathrm{z}$ axis. The voltage vs. time lines for the individual cycles are in greyscale, with the lighter colours corresponding to higher voltage. The charge period of each cycle is the first 600 seconds with the discharge period being the remainder. Hence, charge efficiency of each 
cycle can be measured from the $\mathrm{x}$-axis while the voltage efficiency for each cycle can be calculated from the y-axis.

Each of the cells shows similar charge-discharge profiles during the first few cycles. At the beginning of charge, there is a small voltage peak associated with the nucleation of the $\mathrm{Pb}$ and $\mathrm{PbO}_{2}$ electrode deposits. The voltage then plateaus for the remaining period of charge. On discharge, the voltage is again relatively flat until a sharp drop-off is observed corresponding to the consumption of one or both of the active materials.

\subsubsection{Undivided cells}

The cells without membranes, Lead1 and Bismuth1, begin to show rapidly fluctuating voltage profiles during charge after a relatively small number of cycles $(<10)$, and the discharge times decrease correspondingly. This is symptomatic of electrical shorting between the positive and negative electrodes and is caused by dendrite formation and/or deposit growth/sludging across the bottom of the cell chamber. Following cell cycling, the electrodes typically had residual deposits. The negative electrode residues comprised metallic lead with a number of dendrites evident, and a thick residual layer particularly noticeable at the bottom edge of the electrode. The positive electrode residues comprised a spongy layer of amorphous lead oxides. Without a membrane present, it was clear that electrical shorting was possible between the lead and lead dioxide residues. This is consistent with electrode deposits observed in the soluble lead flow battery [1].

The discharge time and voltage for Bismuth1 is consistently lower than Lead1, being 165 $\mathrm{s}$ at cycle 20 and just $3 \mathrm{~s}$ by cycle 50 for Bismuth 1 and $189 \mathrm{~s}$ and $48 \mathrm{~s}$ correspondingly for 
Lead1. This decrease in cell performance with the presence of $\mathrm{Bi}^{3+}$ at the negative electrode is in agreement with the cyclic voltammetry.

\subsubsection{Membrane divided cells}

A potential adverse effect of including the membrane would be decreased discharge voltages and increased charge voltages as a result of the increased ionic resistance between the positive and negative electrolyte chambers. When comparing similar cells with and without membranes, it can be seen that there is this is not the case. Figure 8 shows the voltage efficiency as a function of cycle number for each of the cells. There is less than $20 \mathrm{mV}$ difference between the charge and discharge voltages of cells Lead1 and Lead2, corresponding to an effective $\mathrm{R}_{\mathrm{mem}}$ of less than $0.13 \Omega$ per cell or $5 \mathrm{~m} \Omega \mathrm{cm}^{-2}$. The voltage efficiency for all cells is above $80 \%$, and there is less fluctuation in the membrane-divided cells, indicating a reduced tenancy for the electrode deposits to form electrically shorting pathways. Figure 8 also shows that as the cells are cycled, the voltage efficiency for cells incorporating a membrane is significantly more stable than for cells without a membrane. The cells without a membrane, Lead1 and Bismuth1, show several sharp fluctuations in voltage efficiency. This is due to lead dendrite formation and corresponds with the voltage vs. time profiles presented in figure 7. With all of the cells, there is a sudden drop in voltage efficiency at the end of the charge discharge cycling which can be attributed to inefficiencies in the charge and discharge reactions leading to a build-up of residues on the electrodes and exhaustion of available $\mathrm{Pb} 2+$ ions in the electrolyte. Hence at this point, during charge the cell is electrolysing water and during 
discharge the insoluble residues on the positive electrode fail to sustain a meaningful cell potential.

Cell failure is defined as when the coulombic efficiency decreases below $70 \%$ or when electrical shorting is observed between the positive and negative electrodes. Table 5 shows the cycle life to failure of all the cells tested (average of 3 cells per configuration) and states the identified failure mode.

The effect of incorporating the membrane into the cell is two-fold: 1) it prevents premature failure via electrical shorting from dendrites, electrode growths and sludge formation and 2) it allows isolation of the additives in each electrode chamber. The cycle life of Bismuth3 was on average 15 times higher than the reference cell, Lead1.

The failure mode seen with the membrane divided cells is related to the depletion of $\mathrm{Pb}^{2+}$ ions in solution through successive cycling at less than $100 \%$ charge efficiency. As can be seen in tables 2 and 3, the coulombic efficiency at each electrode is typically around $80 \%$, and this causes active material to remain on the electrodes after each cycle. This has two effects: (1) The concentration of $\mathrm{Pb}^{2+}$ in the electrolyte decreases. The electrolyte concentration with cycle number is shown in figure 9. The concentration was estimated using Faradays' laws with the coulombic charge efficiency of each cycle, assuming that $100 \%$ of the charge passed was utilised for lead and lead dioxide deposition and dissolution (i.e. no parasitic losses). The decrease in $\mathrm{Pb}^{2+}$ concentration to zero ultimately coincides with cell failure (table 5) and it can be seen that those cells, which preserve the concentration of $\mathrm{Pb}^{2+}$ in the electrolyte, are those with the longest cycle life. (2) $\mathrm{A}$ 
secondary effect of active material build-up is that the voltage efficiency increases with cycling. This is due to the charge voltage decreasing after cycle 1 , and is associated with the residues remaining on the positive electrode at the end of discharge being converted to $\mathrm{PbO}_{2}$ at lower potentials than bulk $\mathrm{PbO}_{2}$ deposition.

\section{TABLE 5}

\section{Conclusions}

This paper demonstrates the first example of a membrane divided soluble lead battery. Incorporating a membrane into this battery system enables the selection and use of electrode specific electrolyte additives. A preliminary trial with $\mathrm{Bi}^{3+}$ ions has shown that the divided cell with $\mathrm{Bi}^{3+}$ in the positive electrode chamber only (Bismuth3) returned improved performance compared to all other cell configurations. The cycle life to failure is 33 cycles, a significant 15 -fold increase compared to the reference cell (Lead1), which failed after 2 cycles. Cell voltage was not adversely affected by the inclusion of the membrane. Two causes of cell failure were observed: 1) electrical shorting and 2) depletion of $\mathrm{Pb}^{2+}$ ions from the electrolyte over successive cycles. Failure of the undivided cells was predominantly due to the former, while failure of the membrane divided cells was principally due to the later.

The cycle life of the cells used in this study is still very low compared to commercial batteries, however, it should be pointed out that the design and construction used was not optimised. The construction was effectively a beaker cell, where mass transport of lead 
ions to and from the electrodes is a significant constraint. This setup, however, allowed rapid testing of the proof-of-concept. Design optimisations including porous 3D electrodes (as apposed to flat plates), systematic studies of alternative membranes and additives along with incorporation of a membrane into a soluble lead flow battery are planned to further develop the concept. 


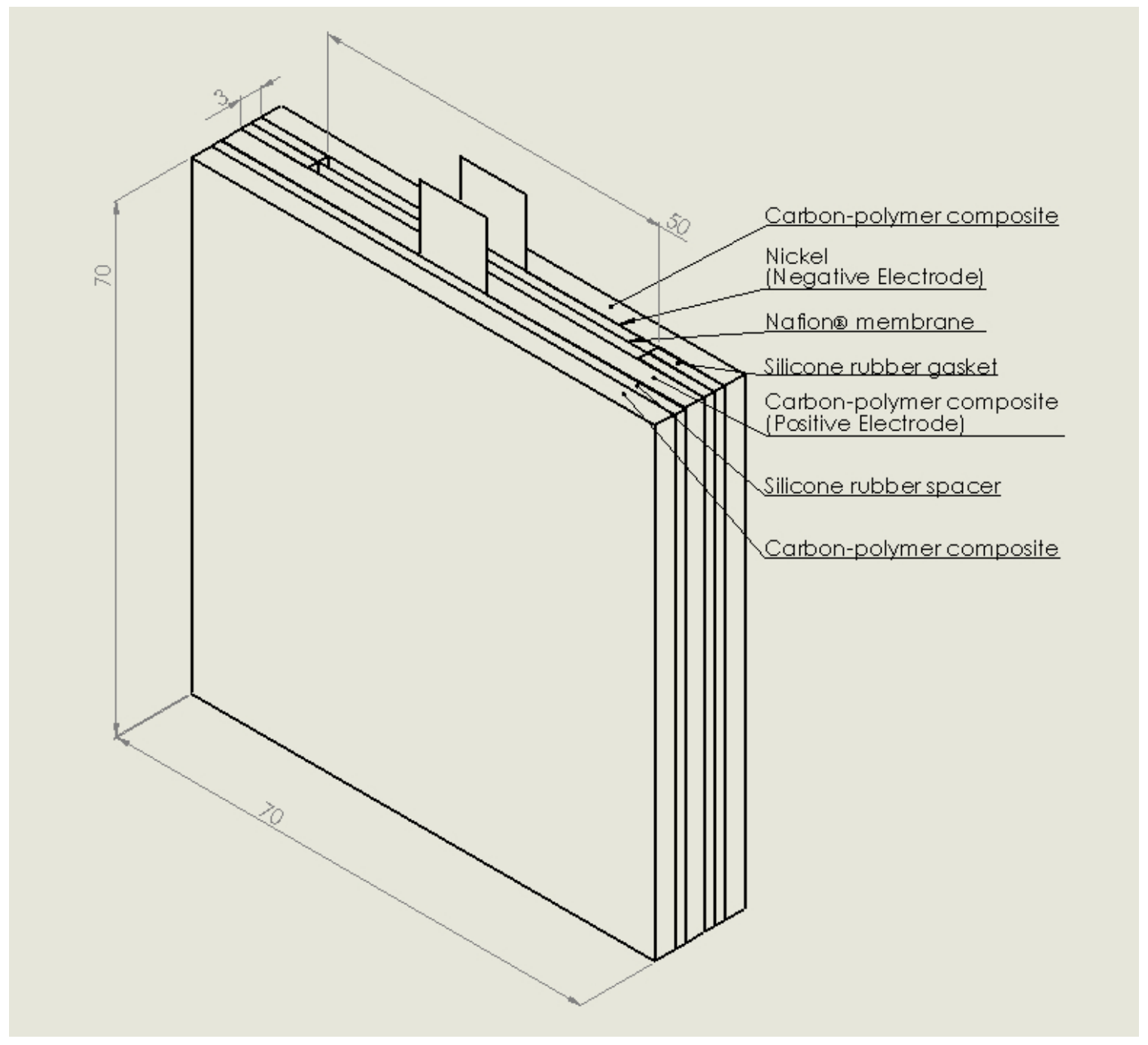

Figure 1: Soluble lead acid cell diagram, showing component materials and dimensions. 


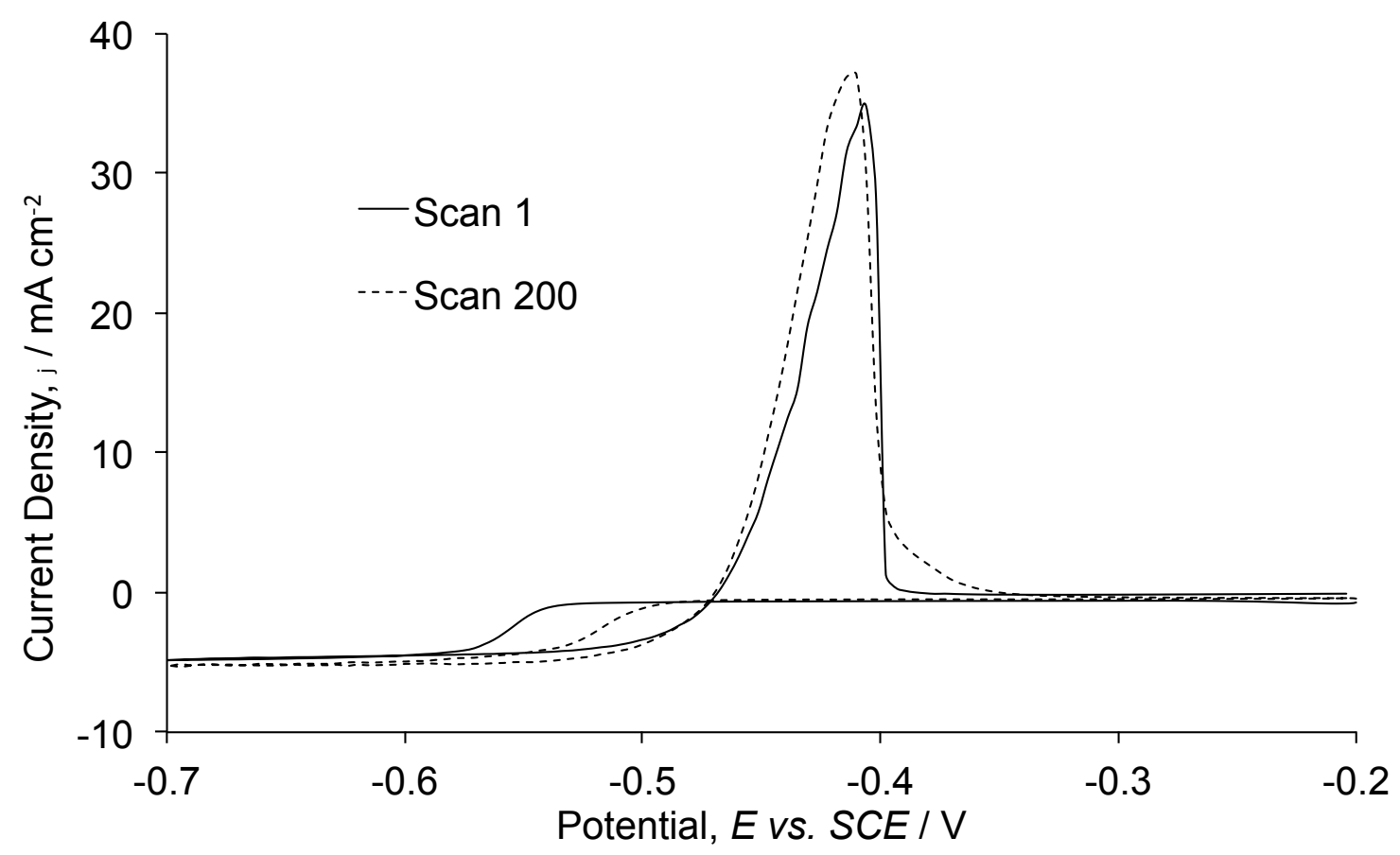

Figure 2: Cyclic voltammograms for the $\mathrm{Pb}^{2+} / \mathrm{Pb}$ electrode couple in methanesulphonic acid $\left(1.5 \mathrm{~mol} \mathrm{dm}^{-3}\right)$ at a glassy carbon rotating disc electrode. Voltammograms show the first and two hundredth consecutive cycle between -0.2 and $-0.7 \mathrm{~V} v$ s. SCE. The electrolyte was maintained at $295 \mathrm{~K}$ and initially contained $10 \mathrm{mmol} \mathrm{dm}^{-3} \mathrm{~Pb}^{2+}$. 

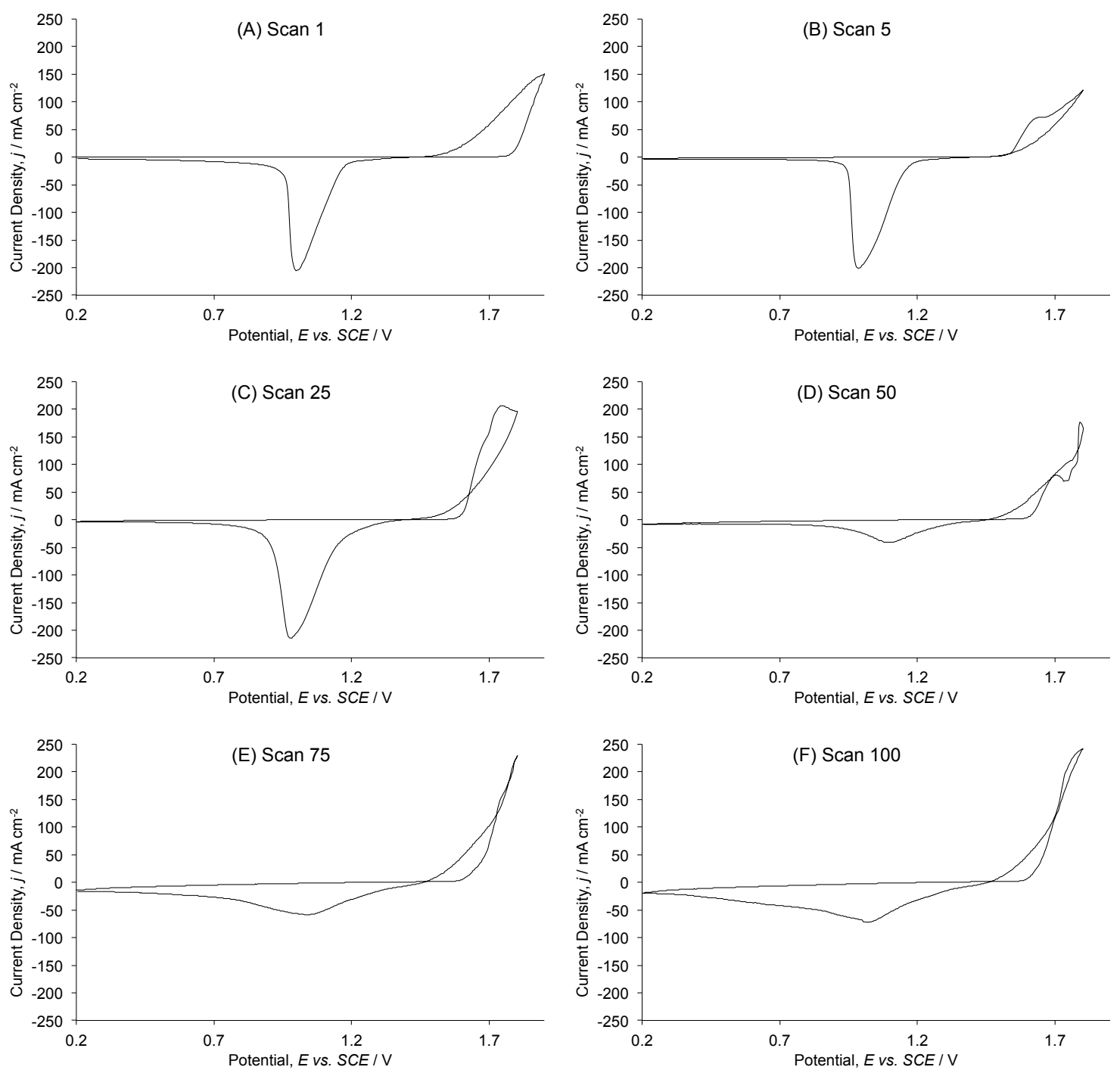

Figure 3: Cyclic voltammograms for the $\mathrm{Pb}^{2+} / \mathrm{PbO}_{2}$ electrode couple in methanesulphonic $\operatorname{acid}\left(1.5 \mathrm{~mol} \mathrm{dm}^{-3}\right)$ at a glassy carbon rotating disc electrode. Voltammograms show the (A) first, (B) fifth, (C) twenty fifth, (D) fiftieth, (E) seventy fifth and (F) one hundredth consecutive cycle between 0.2 and $1.85 \mathrm{~V}$ vs. SCE. The electrolyte was maintained at 295

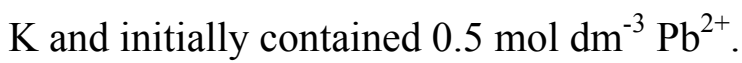




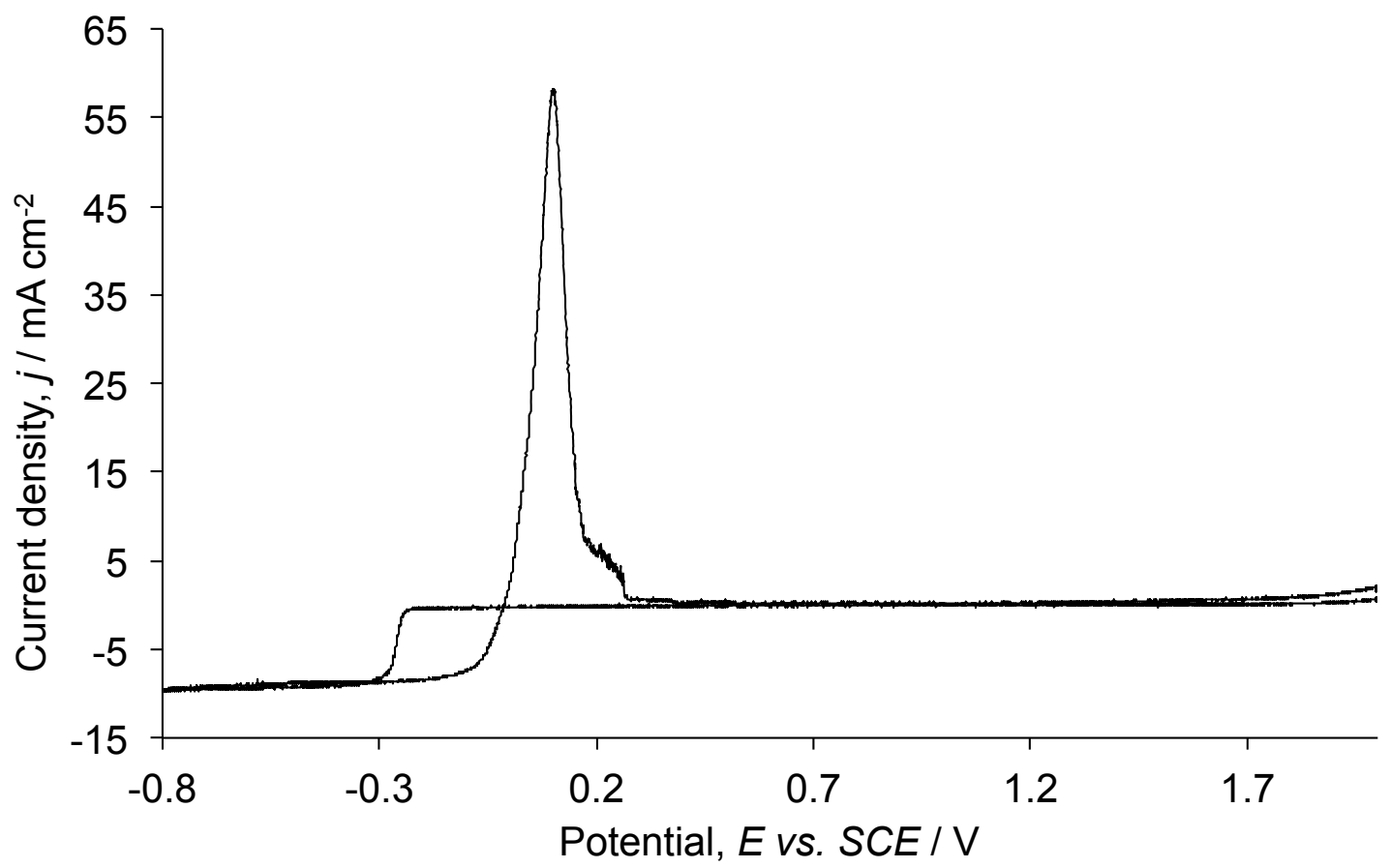

Figure 4: Cyclic voltammogram at a glassy carbon RDE electrode in an elecotlyte containing $\mathrm{Bi}^{3+} 10 \mathrm{mmol} \mathrm{dm}{ }^{-3}$ and methanesulphonic acid $\left(1.5 \mathrm{~mol} \mathrm{dm}{ }^{-3}\right)$ between -0.8 and $1.85 \mathrm{~V} v s$. SCE. The electrolyte was maintained at $295 \mathrm{~K}$. 

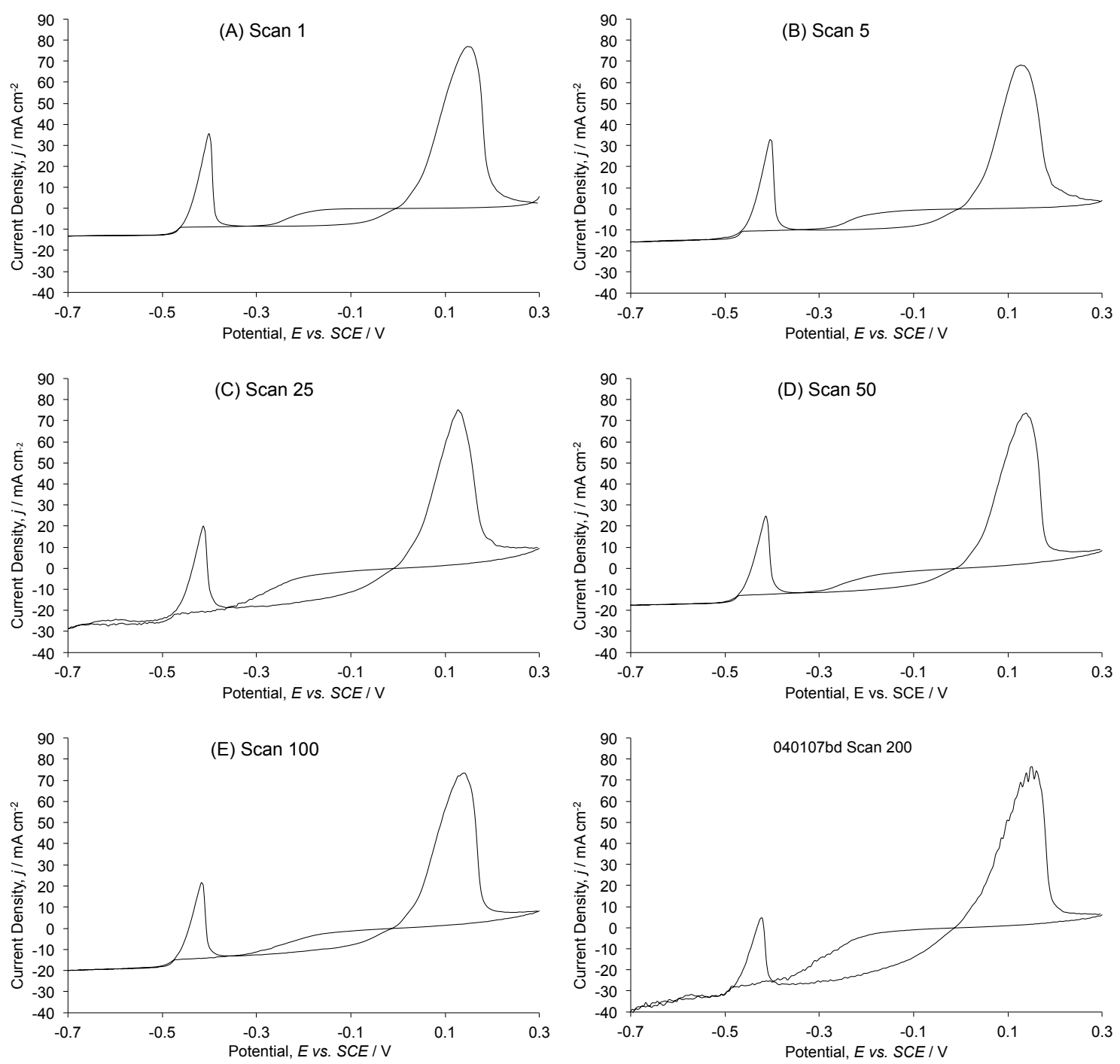

Figure 5: Cyclic voltammograms for the $\mathrm{Pb}^{2+} / \mathrm{Pb}$ electrode couple in methanesulphonic acid $\left(1.5 \mathrm{~mol} \mathrm{dm}^{-3}\right)$ at a glassy carbon rotating disc electrode. The electrolyte initially contained $5 \mathrm{mmol} \mathrm{dm}^{-3} \mathrm{~Pb}^{2+}$ and $10 \mathrm{mmol} \mathrm{dm}^{-3} \mathrm{Bi}^{3+}$. Voltammograms show the (A) first, (B) fifth, (C) twenty fifth, (D) fiftieth, (E) one hundredth and (F) two hundredth consecutive cycle between 0.3 and $-0.7 \mathrm{~V} v$ s. SCE. The electrolyte was maintained at 295 K. 

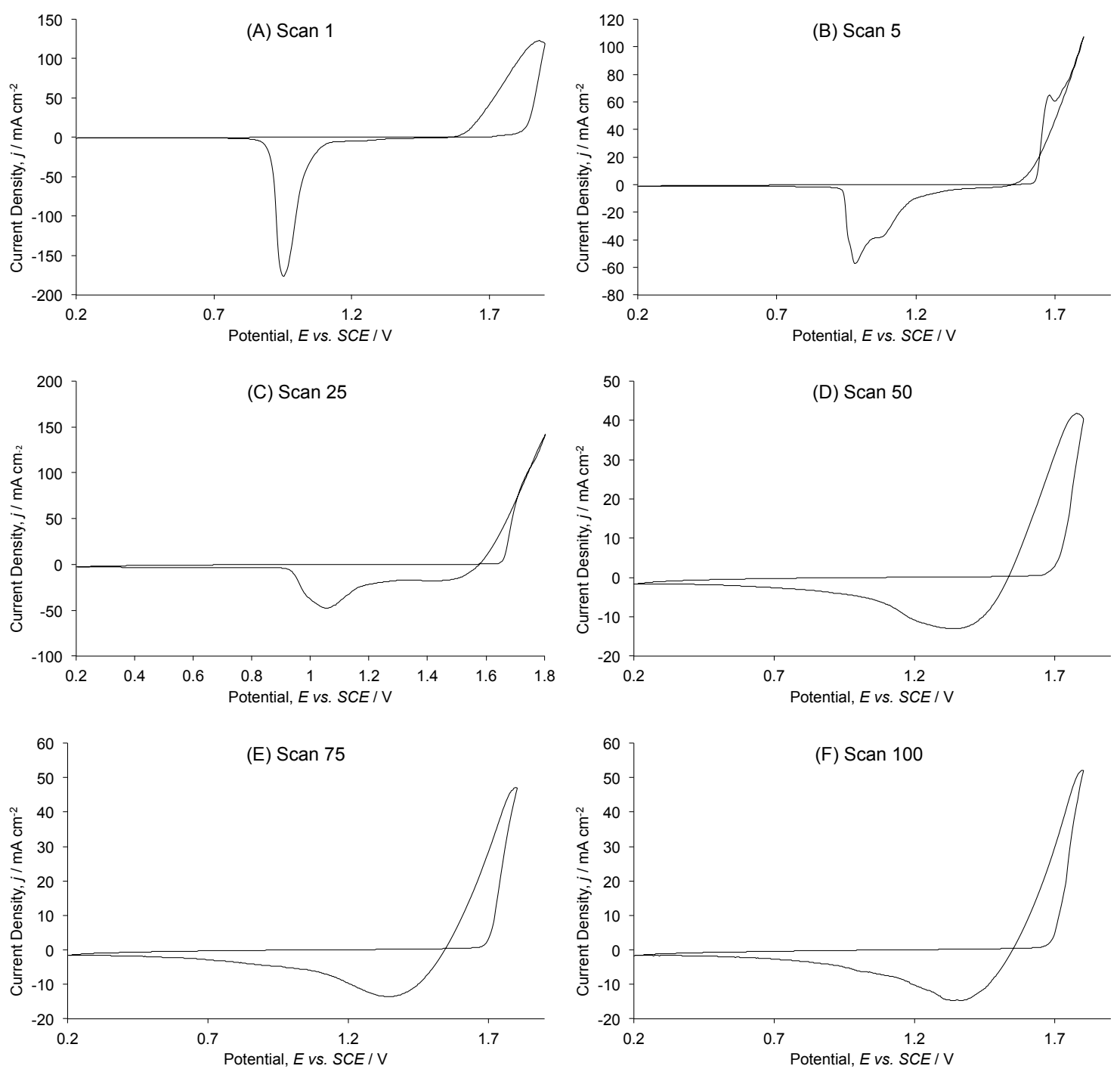

Figure 6: Cyclic voltammograms for the $\mathrm{Pb}^{2+} / \mathrm{PbO}_{2}$ electrode couple in methanesulphonic acid $\left(1.5 \mathrm{~mol} \mathrm{dm}^{-3}\right)$ at a glassy carbon rotating disc electrode. Voltammograms show the (A) first, (B) fifth, (C) twenty fifth, (D) fiftieth, (E) seventy fifth and (F) one hundredth consecutive cycle between 0.2 and $1.85 \mathrm{~V} v$ s. SCE. The electrolyte was maintained at $295 \mathrm{~K}$ and initially contained $0.5 \mathrm{~mol} \mathrm{dm}^{-3} \mathrm{~Pb}^{2+}$ with 10 $\mathrm{mmol} \mathrm{dm}^{-3} \mathrm{Bi}^{3+}$ 
(A)

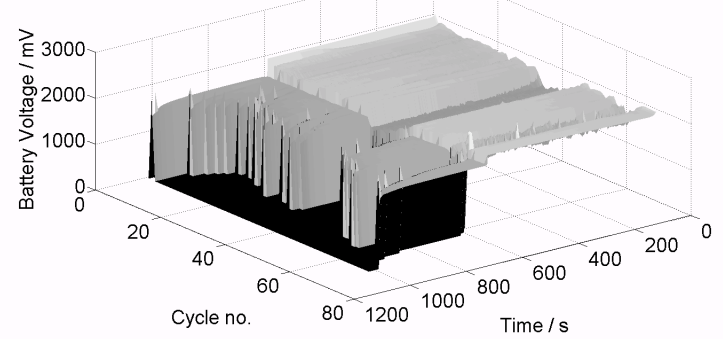

(C)

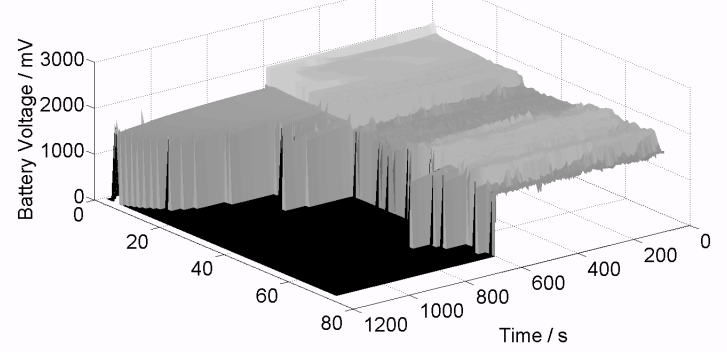

(B)

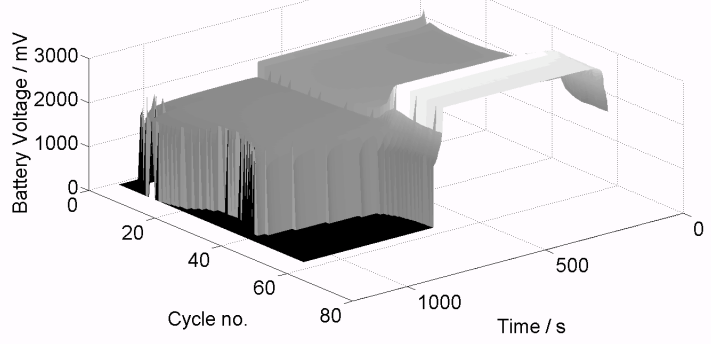

(D)

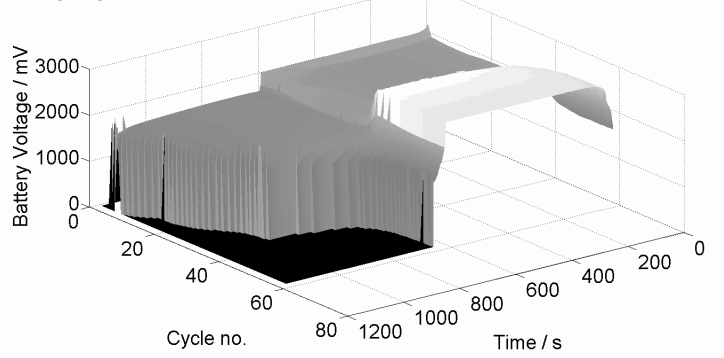

$(\mathrm{E})$

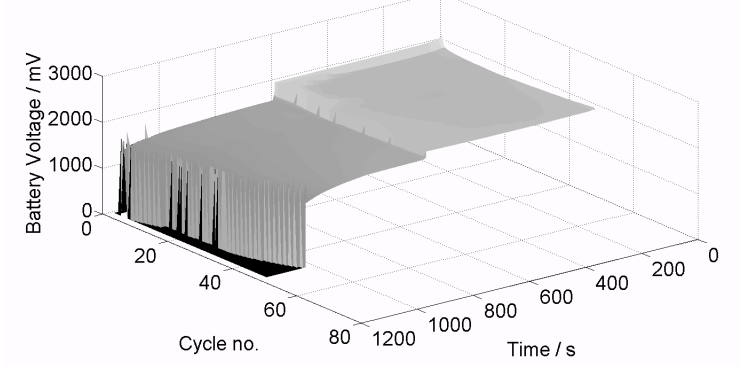

Figure 7: Charge and discharge cycling profile for (A) Lead1, (B) Lead2, (C) Bismuth1, (D) Bismuth2, (E) Bismuth3. Each cycle consists $600 \mathrm{~s}$ charge followed by discharge until the voltage reaches $0 \mathrm{~V}$. A constant current of $150 \mathrm{~mA}$ was used throughout. 


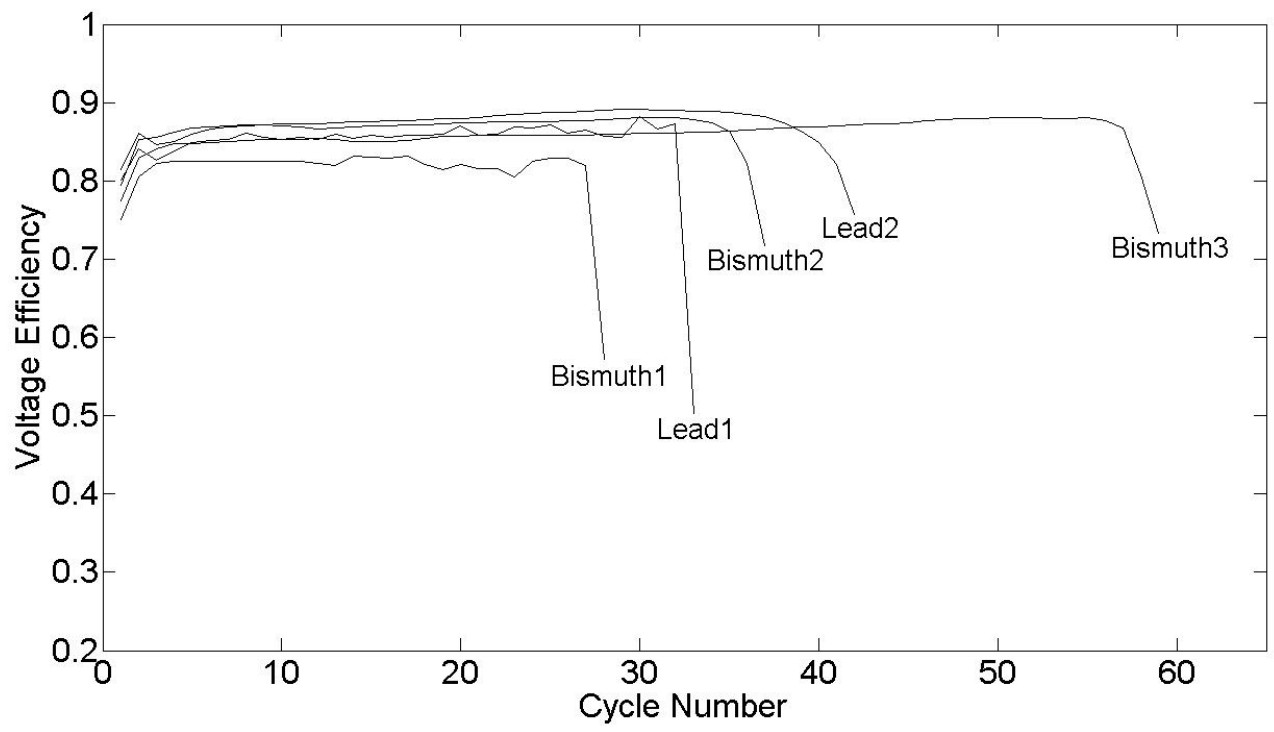

Figure 8: Voltage efficiency as a function of cycle number for each of the cell configurations cells. Cycling at $6 \mathrm{~mA} \mathrm{~cm}^{-2}$, charge for $600 \mathrm{~s}$. $293 \mathrm{~K}$.

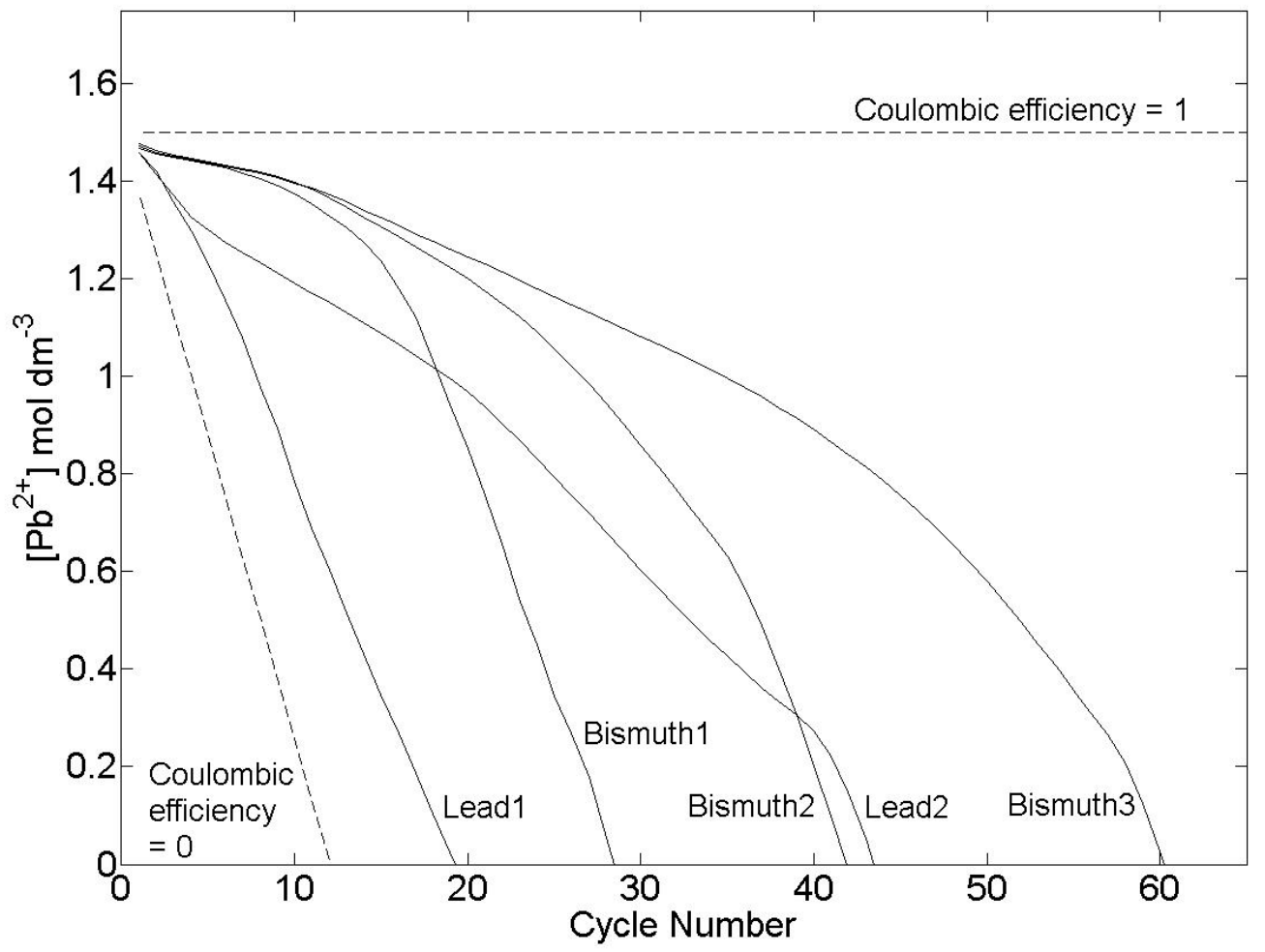


Figure 9: $\left[\mathrm{Pb}^{2+}\right] \mathrm{mol} \mathrm{dm}^{-3}$ in electrolyte during cell cycling at $6 \mathrm{~mA} \mathrm{~cm}{ }^{-2}$, charge for $600 \mathrm{~s}$. $293 \mathrm{~K}$ 
Table 1: Cell configurations and nomenclature

\begin{tabular}{|l|l|l|l|}
\hline Cell identifier & Separator & Additives \\
\cline { 3 - 4 } & & Negative & Positive \\
\hline Lead1 & None & None & None \\
\hline Lead2 & Nafion ${ }^{\circledR}$ & None & None \\
\hline Bismuth1 & None & $10 \mathrm{mM} \mathrm{Bi}^{3+}$ & $10 \mathrm{mM} \mathrm{Bi}^{3+}$ \\
\hline Bismuth2 & Nafion ${ }^{\circledR}$ & $10 \mathrm{mM} \mathrm{Bi}^{3+}$ & $10 \mathrm{mM} \mathrm{Bi}^{3+}$ \\
\hline Bismuth3 & Nafion $^{(B}$ & None & $10 \mathrm{mM} \mathrm{Bi}^{3+}$ \\
\hline
\end{tabular}

Table 2: Pb coulombic efficiency for selected cyclic voltammograms obtained from electrolytes with zero and $10 \mathrm{mmol} \mathrm{dm}^{-3} \mathrm{Bi}^{3+}$.

\begin{tabular}{|l|l|l|l|l|l|l|l|}
\hline \multirow{2}{*}{$\left.\mathbf{m m i}^{\mathbf{3 +}}\right] /$} & \multicolumn{6}{l|}{ Coulombic efficiency / \% } \\
\cline { 2 - 8 } & Scan 1 & Scan 5 & Scan 25 & Scan 50 & Scan 100 & Scan 150 & Scan 200 \\
\hline 0 & 88 & 82 & 83 & 84 & 84 & 84 & 86 \\
\hline 10 & 86 & 76 & 71 & 71 & 64 & 42 & 36 \\
\hline
\end{tabular}

Table 3: $\mathrm{PbO}_{2}$ coulombic efficiency for selected cyclic voltammograms obtained from electrolytes with zero and $10 \mathrm{mmol} \mathrm{dm} \mathrm{mi}^{-3} \mathrm{Bi}^{3+}$.

\begin{tabular}{|l|l|l|l|l|l|l|l|}
\hline \multirow{2}{*}{$\left.\mathbf{m m i}^{3+}\right] /$} & \multicolumn{6}{l|}{ Coulombic efficiency / \% } \\
\cline { 2 - 9 } & Scan 1 & Scan 5 & Scan 25 & Scan 50 & Scan 75 & Scan 100 & Scan 150 \\
\hline 0 & 90 & 92 & 81 & 50 & 78 & 80 & - \\
\hline 10 & 72 & 50 & 65 & 62 & 81 & 80 & 78 \\
\hline
\end{tabular}


Table 4: Equilibrium potential for the $\mathrm{Pb}^{2+} / \mathrm{PbO}_{2}$ electrode couple at $293 \mathrm{~K}$, showing the effect of increasing $\mathrm{Bi}^{3+}$ concentration. The initial electrolyte comprised of methanesulphonic acid $\left(1.5 \mathrm{~mol} \mathrm{dm}^{-3}\right)$ and $0.5 \mathrm{~mol} \mathrm{dm}^{-3} \mathrm{~Pb}^{2+}$.

\begin{tabular}{|l|l|}
\hline$\left[\mathbf{B i}^{3+}\right] / \mathbf{m m o l ~ d m}^{-3}$ & Equilibrium potential, $E_{P b O_{2} / P b^{2+}}^{\theta} \boldsymbol{v s .}$ SCE / V \\
\hline 0 & 1.440 \\
\hline 2 & 1.555 \\
\hline 10 & 1.630 \\
\hline 20 & 1.651 \\
\hline
\end{tabular}

Table 5 Cell cycle life and failure mode. The values are averages of five sets of experimental data.

\begin{tabular}{|l|l|l|}
\hline Cell & Cycles to failure & Failure mode \\
\hline Lead1 & 2 & Electrical shorting from dendrite formation \\
\hline Lead2 & 14 & $\mathrm{~Pb}^{2+}$ depletion from electrolyte \\
\hline Bismuth1 & 15 & Electrical shorting from dendrite formation \\
\hline Bismuth2 & 20 & $\mathrm{~Pb}^{2+}$ depletion from electrolyte \\
\hline Bismuth3 & 33 & $\mathrm{~Pb}^{2+}$ depletion from electrolyte \\
\hline
\end{tabular}




\section{References}

[1] R.G.A. Wills, J. Collins, D. Stratton-Campbell, C.T.J. Low, D. Pletcher, F.C. Walsh, Journal of Applied Electrochemistry 40 (2010) 955.

[2] J. Collins, G. Kear, X. Li, C.T.J. Low, D. Pletcher, R. Tangirala, D. StrattonCampbell, F.C. Walsh, C. Zhang, Journal of Power Sources 195 (2010) 1731.

[3] A. Hazza, D. Pletcher, R.G.A. Wills, Physical Chemistry Chemical Physics 6 (2004) 1773.

[4] M.G. Verde, K.J. Carroll, Z. Wang, A. Sathrum, Y.S. Meng, Energy and Environmantal Science 2013.

[5] A.A. Shah, X. Li, R.G.A. Wills, F.C. Walsh, Journal of the Electrochemical Society 157 (2010) A589.

[6] A. Oury, A. Kirchev, Y. Bultel, Journal of The Electrochemical Society 160 (2013) A148.

[7] D. Pletcher, H. Zhou, G. Kear, C.T.J. Low, F.C. Walsh, R.G.A. Wills, Journal of Power Sources 180 (2008) 630.

[8] D. Pletcher, H. Zhou, G. Kear, C.T.J. Low, F.C. Walsh, R.G.A. Wills, Journal of Power Sources 180 (2008) 621.

[9] S. Zhong, H. K. Liu, S. X. Dou, M. Skyllas-Kazacos, Journal of Power Sources 59 (1996) $123-129$

[10] L.T. Lam, N. P. Haigh, D. A. J. Rand, Journal of Power Sources 88 (2000) 11-17.

[11] D. Pletcher, R.G.A. Wills, Physical Chemistry Chemical Physics 6 (2004) 1779. 